\title{
Verzeichnis
}

\section{der Herren, welche für den vierundzwanzigsten Band Referate geliefert haben.}

(Die Verantwortlichkeit für den Inhalt der Referate tragen die Herren Referenten. Die in Klammern gesetzten Chiffern bezeichnen die Uebersetzer der in fremder Sprache eingesandten Referate.)

A. Herr Prof. August in Berlin.

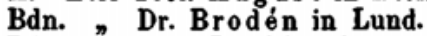
Bdt. " Prof. Burkhardt in Göttingen.

Bk. , Prof. Buka in Charlottenburg.

Bm. „ Prof. v. Braunmühi in München.

Bö. „ Prof. Börsch in Potsdam.

Br. \# Dr. Brix in Berlin.

Cly. " Prof. Cayley in Cam. bridget.

Dml. , Dr. Demoulin in Gent.

Dn. "Dickstein in Warschau.

Dz. " Prof. Dziobek in Char-

E. $\quad$ Prof. Eneström in lottenburg.

E.K. Prof. E. Kötter in Berlin.

EI. " Prof. Engel in Leipzig.

F. " Dr. Faerber in Berlin.

F.K. " Prof. F. Kötter in Berlin.

Gbs. " Assist. Prof. Gibson in

Glr. Prof. Glaisher in Glasgow.

Gz. „ Dr. Gutzmer in Berlin.

H. $~ ᄁ$ Prof. Hoppe in Berlin.

Hae. ” Dr. Haentzschel in Berlin.

Hau., Dr. Haussner in Würzburg.

Hk. „ Prof. Hauck in Berlin.

Ho. " Dr. Horn in Charlottenburg.

Hr. " Prof. Hamburger in Berlin.

Ht. " Prof. Hil bert in Göttingen.

Hz. " Prof. Hurwitz in Zürich.

Jk. " Prof. Joukovsky in

Js. Moskau.

s. " Prof. Jolles in Villen-

Kr. " Prof. Krazer in Strassburg i. E.
La. Herr Prof. Loria in Genua.

Lg. " Prof. Lange in Berlin.

Lh. $\quad$ Dr. Lerch in Prag.

Lp. " Prof. L a mpe in Berlin.

M. " Prof. F. Muller in Berlin.

Mh. " Dr. Meth in Berlin.

Mi. $"$ Dr. Michaelis in Berlin.

Mn. " Prof..Mansion in Gent.

Mo. n Dr. Molenbroek im Haag.

My. " Prof. F. Meyer in Clausthal.

Mz. " Prof. M a ynz in Ludwigslust.

N. " Prof. C. Neumann in

I,eipzig.

R.M. $\cap$ Dr. R. Müller in Berlin.

Sbt. " Dr. Siebert in Gross-

Schg. Prof. Schlegel

Prof Schubertin Hambur

Sfs. "Prof. Schönflies in

Sh. „Dr. Schafb'eitlin in Char-

Si. lottenburg.

Si. $\cong$ Dr. Sintzow in Kasan.

Sn. " Dr. P. Simon in Bonn.

St. " Prof. Stãckel in Kö̀nigs-

Std. „ Prof. Studnička in Prag.

Tn. " Prof. Treutlein in

Karlsruhe.

Tx. ॠ Prof. Teixeira in Porto.

V. "Dr. Valentiner in Kopenhagen.

Vi., Dr. Vivanti in Mantua.

Vrs. "Prof. de Vries in Delft.

Wbg." " Dr. Wallenberg in Berlin.

Wi. " Prof. A. Wassilieff in

Wn. $n$ Prof. Wangerin in Kasan.

Prof. Weltzien in Halle a. S. dorf.

Briefe und Zusendungen erbitten wir entweder durch Vermittelung der Verlagshandlung oder unter der Adresse:

Professor Dr. Lampe, Berlin W., Kurfürstenstr. 139. 